\title{
Design of Real-Time Aquarium Monitoring System for Endemic Fish on the Smartphone
}

\author{
Naufal Inas Fikri, Vito Louis Nathaniel, Muchamad Syahrul Gunawan, Tomy Abuzairi* \\ Electrical Engineering, Department of Electrical Engineering, Faculty of Engineering, Universitas Indonesia, Depok, Indonesia
}

\section{ARTICLE INFO}

\section{Article history:}

Received July 18, 2021

Revised August 10, 2021

Accepted August 28, 2021

\section{Keywords:}

Endemic Fish; ESP32;

Temperature;

$\mathrm{pH}$ level;

Camera;

Smartphone

\begin{abstract}
The high rate of decreasing population of endemic fish species is becoming more severe over time. Therefore, it needed an effort to bring back the stability of the number. One of the reasons for the decreasing population is the changing environment due to climate change and the difficulty of treatment for this species. This research aims to design an aquarium monitoring system for endemic fish. The main components for this system are microcontroller ESP32 DOIT, Temperature Sensors DS18B20, DF Robot Analog pH Sensors, ESP32 Cam, UV Lamp, and Blynk server. The experiment was conducted by monitoring the aquarium environment using sensors and comparing it with the reference sensors. With a monitoring system, we can find out whether the current condition of the aquarium is in accordance with the fish's living environment or not. The monitoring results show that the average error for temperature is $0.14 \%$ and for $\mathrm{pH}$ is $0.67 \%$. These results indicate that the prototype sensors are linear with reference sensors. Besides that, a real-time monitoring system is easy to use and more attractive because of smartphone utilization to monitor fish with a camera and lamp.
\end{abstract}

This work is licensed under a Creative Commons Attribution-Share Alike 4.0

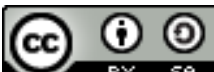

\section{Tomy Abuzairi,}

Electrical Engineering, Department of Electrical Engineering, Faculty of Engineering, Universitas Indonesia, Indonesia Email: tomy.abuzairi@ui.ac.id

\section{INTRODUCTION}

Indonesia is an archipelagic country with a tropical climate rich in biodiversity or commonly called "Mega-biodiversity" [1][2]. As an archipelagic country, Indonesia covers around 5,193,250 million $\mathrm{km}^{2}$ area, where two-thirds of Indonesia's territory is a water area of 3.25 million $\mathrm{km}^{2}$ [3][4]. The area of water that is larger than the mainland makes Indonesia rich in fish species. There are 4,782 fish species recorded in Indonesia, and about 130 are endemic species [5]. Endemic species are species that grow naturally in only one geographic area. Naturally, The factors that cause the endemism of animals are temperature, humidity, and wind [6].

However, this diversity is not in line with public awareness to maintain and preserve the diversity of endemic fauna. It is characterized by being very rare and difficult to find in its natural habitat [7]. This problem has occurred for a long time but has not been resolved until now. Moreover, water temperature has an important role in fish development activities. Rapid temperature increases are known to cause acute stress responses and expose fish to disease. In addition, highly fluctuated temperatures can cause fish death [8][9]. In addition, a good $\mathrm{pH}$ content for fish waters generally ranges from 5-9. Inappropriate $\mathrm{pH}$ content can cause fish vulnerability to parasites, growth to slow down, cause physiological disturbances in fish, and decrease the survival of fish [10][11].

The Internet of Things (IoT) refers to a network to connect anything with the Internet. Internet of Things enables one device to control and monitor other devices in the same network [12][13]. Currently, the development of IoT is very rapid. It has allowed for various possibilities in technological advancements for different aspects of life [14][15]. With the condition of endemic fish habitat becoming concerning and overexploited increasingly, the application of IoT-based technology that is integrated with sensors and 
actuators makes Ex-Situ conservation more and more well-monitored and controlled. However, the current smart aquarium system can only monitor the quality of the water in the aquarium without displaying the visual state of the aquarium in real-time [16]. Table 1 shows a comparison of the features possessed by the related works. This study aims to design an aquarium system to monitor (temperature and $\mathrm{pH}$ ) and display the aquarium's condition using a camera in real-time. The research contribution is to apply technology for monitoring in Ex-situ conservation.

Table 1. Comparison of features of related works.

\begin{tabular}{|c|c|c|c|c|c|c|}
\hline References & $\mathrm{pH}$ & Temperature & TDS & Turbidity & Camera & Lamp \\
\hline$[17]$ & $\checkmark$ & $\checkmark$ & - & - & - & - \\
\hline$[18]$ & $\checkmark$ & - & $\checkmark$ & - & - & - \\
\hline$[19]$ & $\checkmark$ & $\checkmark$ & - & - & - & - \\
\hline$[20]$ & $\checkmark$ & $\checkmark$ & $\checkmark$ & $\checkmark$ & - & - \\
\hline$[21]$ & - & $\checkmark$ & - & - & - & - \\
\hline This work & $\checkmark$ & $\checkmark$ & - & - & $\checkmark$ & $\checkmark$ \\
\hline
\end{tabular}

\section{RESEARCH METHOD}

Fig. 1 and Fig. 2 show the design and block diagram of the prototype. The main components for this system are microcontroller ESP32 DOIT, Temperature Sensors DS18B20, DF Robot Analog pH Sensors, ESP32 Cam, UV Lamp, and Blynk server.

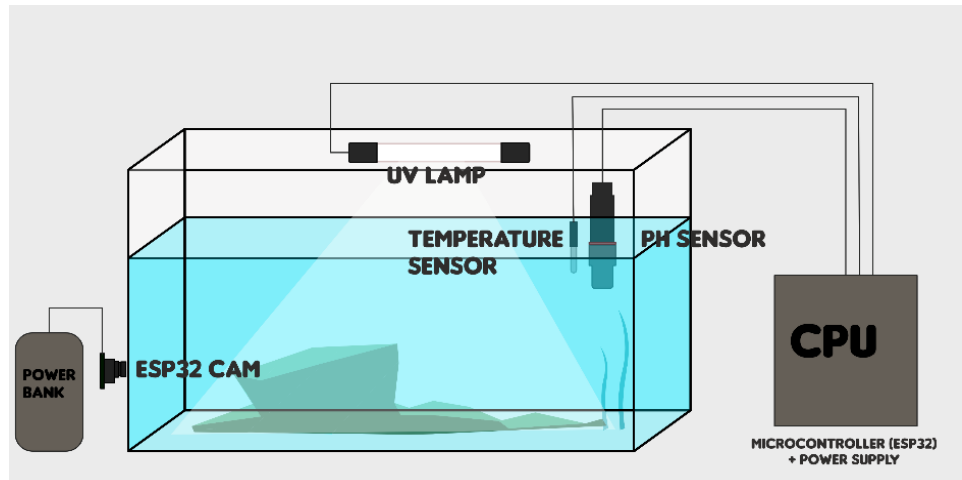

Fig. 1. Design of prototype.

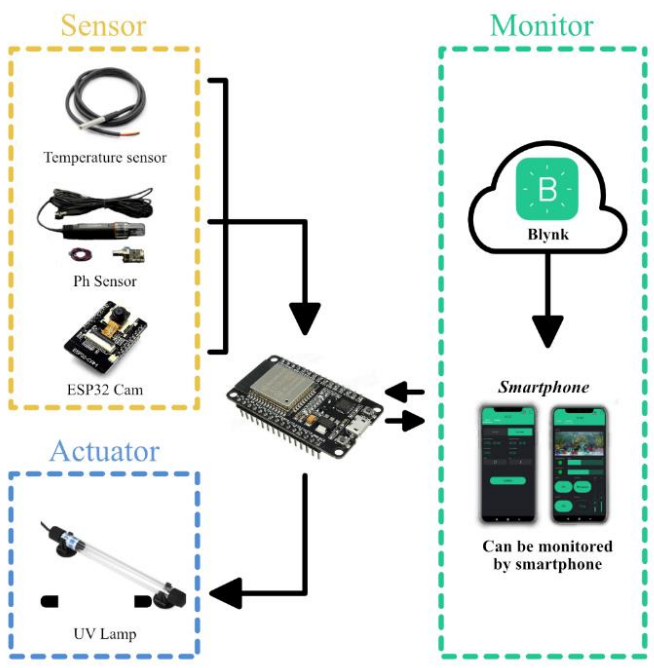

Fig. 2. Prototype block diagram.

PCB design and wiring tool are shown in Fig. 3. This prototype uses the ESP32 Development board as the main microcontroller, which is powered by a dual-core Tensilica Xtensa LX6 microprocessor [22][23]. 
Its minimalist design but equipped with a WiFi module makes the ESP32 a good microcontroller for IoT development. The DS18B20 is a waterproof temperature sensor used to measure liquids, soils, or solutions. The temperature sensor DS18B20 has a temperature measurement range from $-55^{\circ} \mathrm{C}$ to $125^{\circ} \mathrm{C}$ and uses a 3.0-5.0 V supply for its operation [24][25]. In reading the aquarium water temperature, we use the DS18B20 sensor, changing the temperature value to voltage. The $\mathrm{pH}$ sensor used in this system is the DFRobot sensor kit which has a measuring range of 0-14 with accuracy \pm 0.1 and response time $\leq 1 \mathrm{~min}$ [26]. This sensor works with a working voltage of $5 \mathrm{~V}$, so it is easy to integrate with a microcontroller [27]. The camera functions as a monitoring tool for fish and aquarium conditions. The camera will be connected to the IoT server so that users can see the condition of the aquarium from anywhere. In this prototype, we use the ESP32 Cam as a camera module which has a small size board with a footprint of $27 \times 40.5 \times 4.5$ millimeters. The ESP32-Cam uses an OV2640 camera module. It can operate with a maximum resolution of 1600x1200 pixels at fifteen frames per second [28]. UV lamps are used to reduce the viability of the fish pathogenic bacterium [29].

The smartphone application for this prototype is utilized the Blynk platform. Blynk is an IoT platform that enables the development and implementation of smart IoT devices with ease and speed. With Blynk, all the sensor data can be observed in real-time easily from our smartphones, and the user can also give orders to the prototype [30][31]. This can be facilitated because Blynk provides cloud services to exchange information between tools and users. In addition, the application also has an additional feature that is a reminder that will notify users if the aquarium conditions are outside normal limits. Users can enter the limits for normal conditions of temperature and $\mathrm{pH}$ in the application. So, if the condition of the aquarium water is not between these normal limits, then the application in the smartphone will send a notification to the user's smartphone.
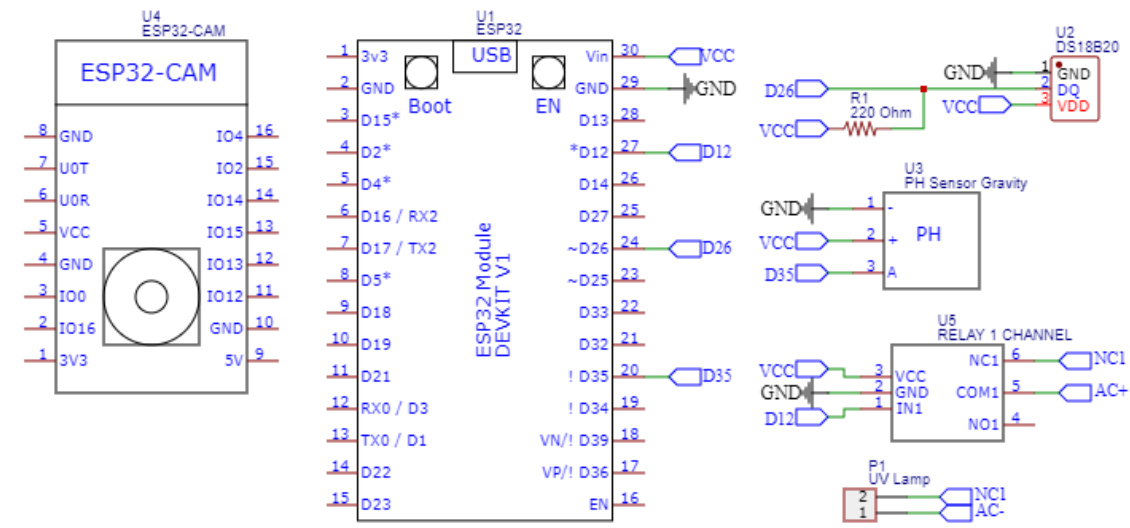

Fig. 3. Schematic circuit of the prototype.

\section{RESULTS AND DISCUSSION}

Data collection using the prototype is shown in Table 2 for temperature measurement and Table 3 for $\mathrm{pH}$ measurement. The prototype was tested in an aquarium with dimensions of $90 \times 40 \times 40 \mathrm{~cm}^{3}$ filled with 77 liters of water, as shown in Fig. 4. The fish used as the subject for this prototype is the Sepat Mutiara (Trichopodus leeri).

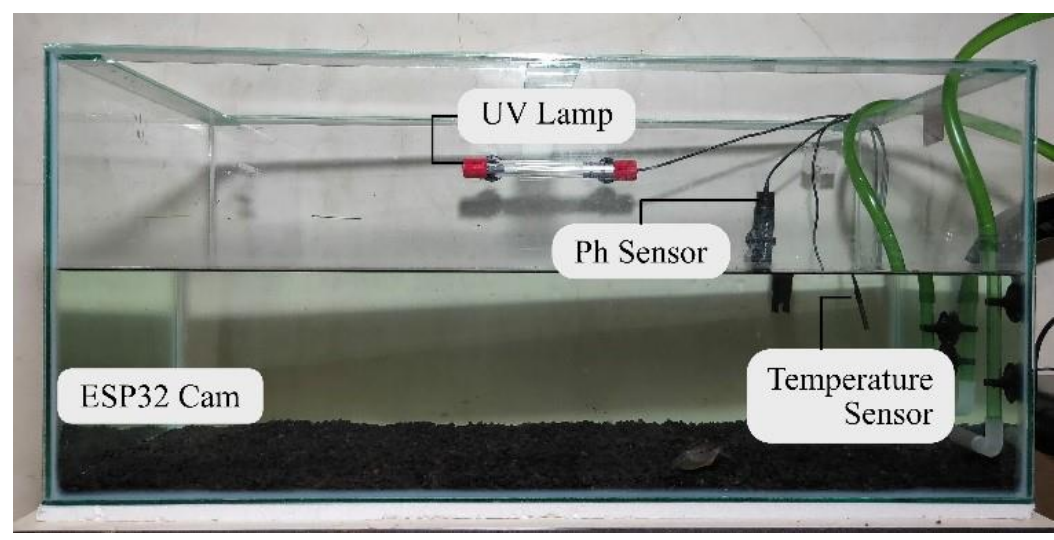

Fig. 4. View of the prototype. 
Table 2 shows the average error data from the temperature test. Error data is obtained by comparing the temperature read by the DS18B20 sensor and the reference temperature every 5 minutes, five times each day, for three days. From the test, the average error for temperature is $0.14 \%$. The linear temperature relationship of the prototype with the reference is shown in Fig. 5.

Table 2. Data accuracy measurements of temperature.

\begin{tabular}{|c|c|c|c|c|}
\hline Day & $\begin{array}{c}\text { Time } \\
\text { Sampling }\end{array}$ & $\begin{array}{c}\text { Prototype } \\
\text { temperature } \\
\left({ }^{\circ} \mathrm{C}\right)\end{array}$ & $\begin{array}{c}\text { Reference } \\
\text { Temperature } \\
\left({ }^{\circ} \mathbf{C}\right)\end{array}$ & Error rate \\
\hline \multirow{5}{*}{1} & 1 & 29.94 & 29.9 & $0.13 \%$ \\
\hline & 2 & 29.94 & 29.9 & $0.13 \%$ \\
\hline & 3 & 29.94 & 29.9 & $0.13 \%$ \\
\hline & 4 & 29.94 & 29.9 & $0.13 \%$ \\
\hline & 5 & 29.94 & 29.9 & $0.13 \%$ \\
\hline Mean 1 & & & & $0.13 \%$ \\
\hline \multirow{5}{*}{2} & 1 & 29.95 & 29.9 & $0.17 \%$ \\
\hline & 2 & 29.95 & 29.9 & $0.17 \%$ \\
\hline & 3 & 29.95 & 29.9 & $0.17 \%$ \\
\hline & 4 & 29.95 & 29.9 & $0.17 \%$ \\
\hline & 5 & 29.95 & 29.9 & $0.17 \%$ \\
\hline Mean 2 & & & & $0.17 \%$ \\
\hline \multirow{5}{*}{3} & 1 & 30.04 & 30.0 & $0.13 \%$ \\
\hline & 2 & 30.04 & 30.0 & $0.13 \%$ \\
\hline & 3 & 30.04 & 30.0 & $0.13 \%$ \\
\hline & 4 & 30.04 & 30.0 & $0.13 \%$ \\
\hline & 5 & 30.04 & 30.0 & $0.13 \%$ \\
\hline Mean 3 & & & & $0.13 \%$ \\
\hline Average & & & & $0.14 \%$ \\
\hline
\end{tabular}

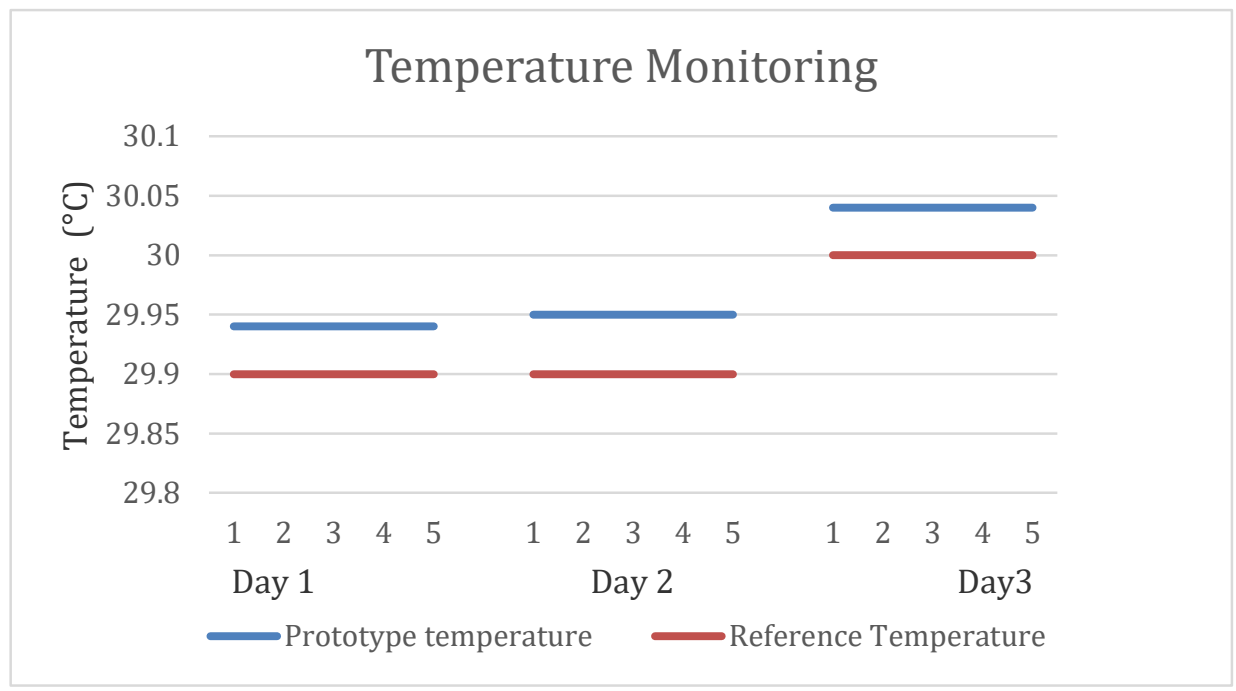

Fig. 5. Comparison temperature between prototype and reference.

Table 3 shows the average error data from the $\mathrm{pH}$ test. The error data is obtained by comparing the temperature read by the $\mathrm{pH}$ analog sensor and the reference $\mathrm{pH}$ in 5-minute intervals, five times each day, for three days. From the test, the average error for $\mathrm{pH}$ is $0.67 \%$. The $\mathrm{pH}$ linear relationship of the prototype with the reference is shown in Fig. 6. 
Table 3. Data accuracy measurements of $\mathrm{pH}$.

\begin{tabular}{|c|c|c|c|c|}
\hline Day & $\begin{array}{c}\text { Time } \\
\text { Sampling }\end{array}$ & $\begin{array}{c}\text { Prototype } \\
\text { pH }\end{array}$ & Reference pH & Error rate \\
\hline \multirow{5}{*}{1} & 1 & 7.89 & 7.8 & $1.15 \%$ \\
\hline & 2 & 7.93 & 7.9 & $0.38 \%$ \\
\hline & 3 & 8.02 & 7.9 & $1.52 \%$ \\
\hline & 4 & 7.83 & 7.9 & $0.89 \%$ \\
\hline & 5 & 7.87 & 7.9 & $0.38 \%$ \\
\hline Mean 1 & & & & $0.86 \%$ \\
\hline \multirow{5}{*}{2} & 1 & 7.92 & 7.9 & $0.25 \%$ \\
\hline & 2 & 7.90 & 7.9 & $0 \%$ \\
\hline & 3 & 7.97 & 7.9 & $0.89 \%$ \\
\hline & 4 & 7.94 & 7.9 & $0.51 \%$ \\
\hline & 5 & 7.87 & 7.8 & $0.9 \%$ \\
\hline Mean 2 & & & & $0.51 \%$ \\
\hline \multirow{5}{*}{3} & 1 & 7.98 & 8.0 & $0.25 \%$ \\
\hline & 2 & 8.12 & 8.0 & $1.5 \%$ \\
\hline & 3 & 8.05 & 8.0 & $0.625 \%$ \\
\hline & 4 & 7.97 & 8.0 & $0.375 \%$ \\
\hline & 5 & 8.03 & 8.0 & $0.375 \%$ \\
\hline Mean 3 & & & & $0.63 \%$ \\
\hline Average & & & & $0.67 \%$ \\
\hline
\end{tabular}

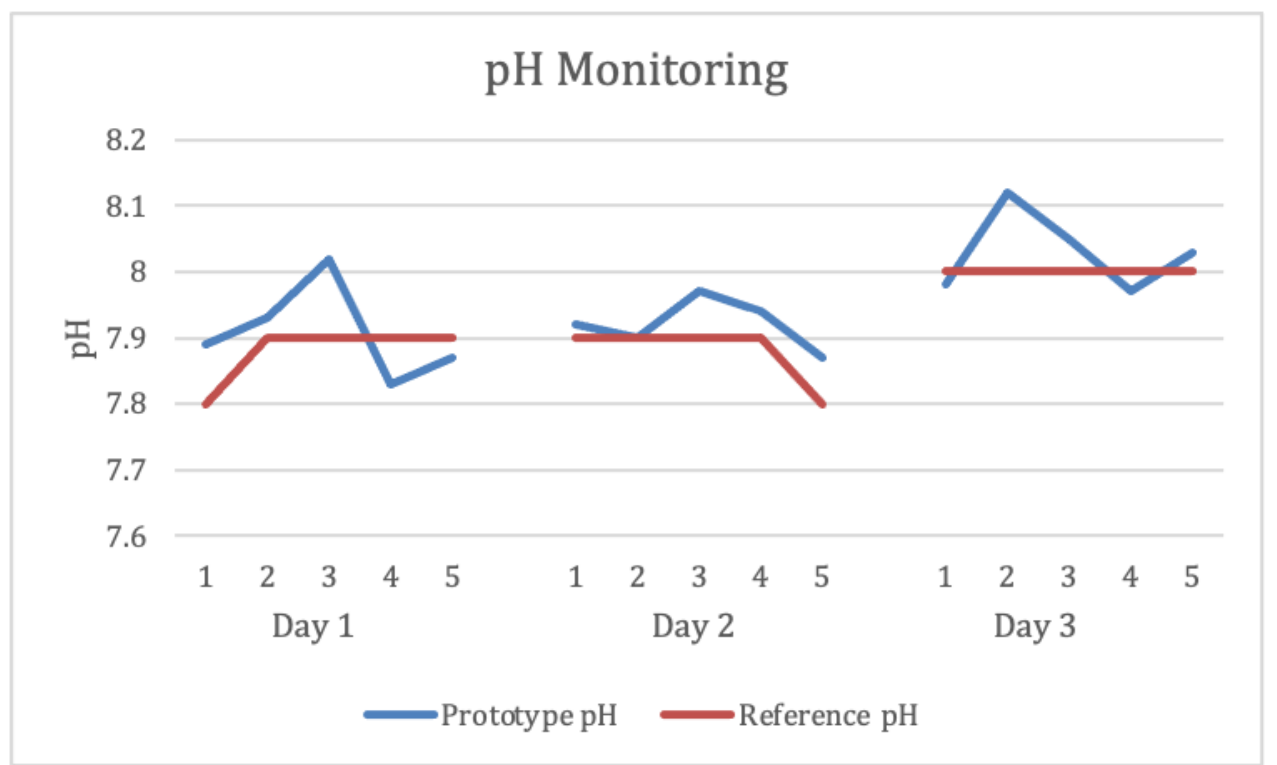

Fig. 6. Comparison $\mathrm{pH}$ between prototype and reference.

In addition to obtaining the $\mathrm{pH}$ and temperature data, we also tested other features of the prototype, such as a camera, UV lamp, and the use of a web server for setting Wi-Fi credentials. Based on the experiment, we found that the best resolution of the ESP32-Cam for monitoring the aquarium of $90 \times 40 \times 40 \mathrm{~cm}^{3}$ is $640 \times 480$ pixels. This resolution will have a good image quality with a short rendering time. At the same time, the use of UV lamps in our aquarium is very useful for lighting and monitoring the aquarium, as shown in Fig. 7. Besides that, UV lamps also can inhibit the growth of bacteria. 


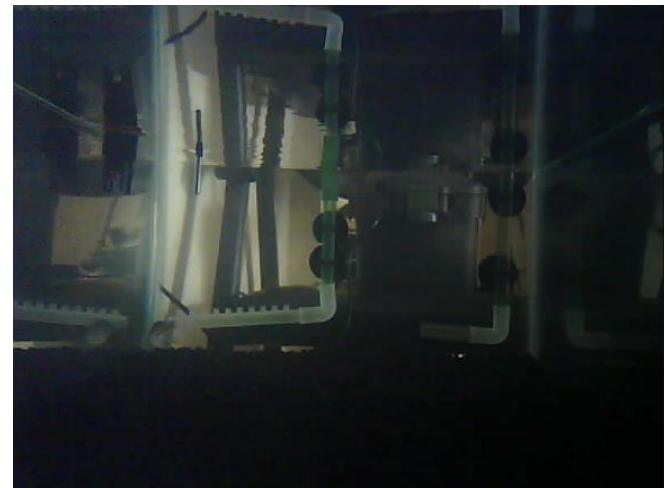

(a)

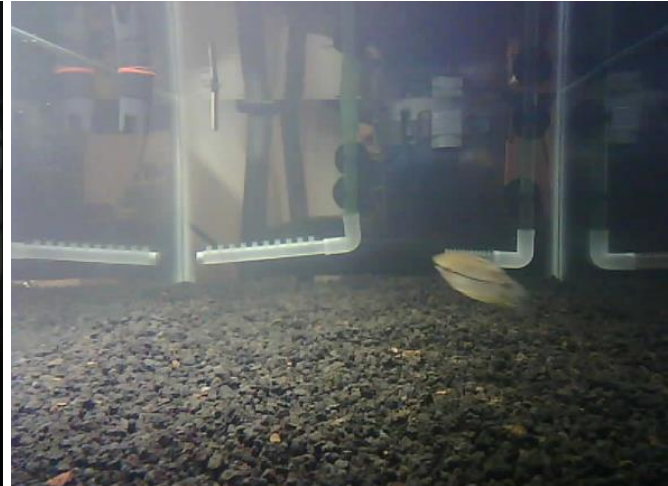

(b)

Fig. 7. Without lamp (a) and with lamp (b) view in the aquarium.

Fig. 8(a) shows the Blynk Graphical User Interface, which displays a real-time visual view of the aquarium, the value of temperature and $\mathrm{pH}$ level, time scheduler for lighting, and a graphic of temperature and $\mathrm{pH}$ level that stores data up to 3 months. Fig. 8(b) displays a webserver display to change the WiFi network so that users do not need to reprogram the hardcode of the ESP32 to switch networks. Fig. 8(c) shows a warning system that will notify if the monitored temperature or $\mathrm{pH}$ exceeds the limit set in the blynk application.

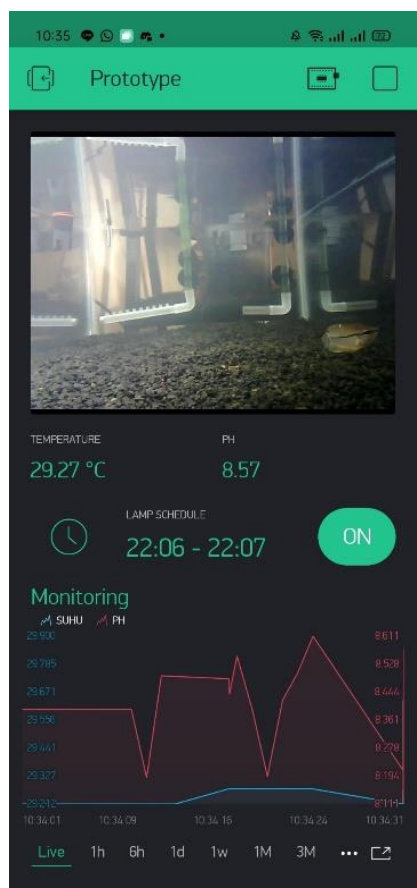

(a)

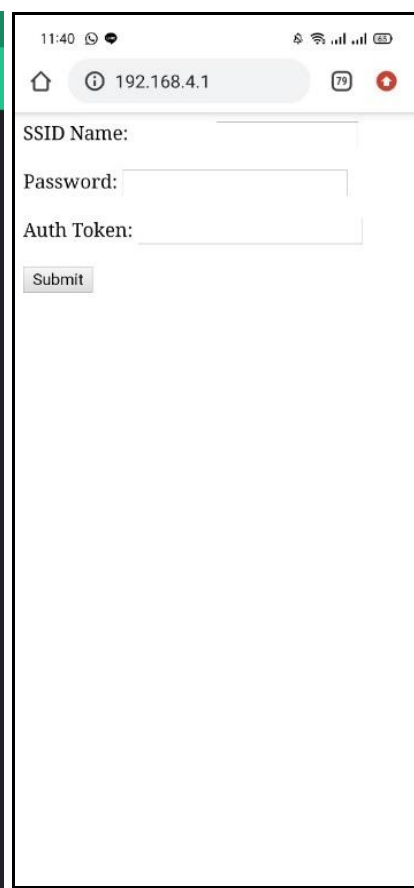

(b)

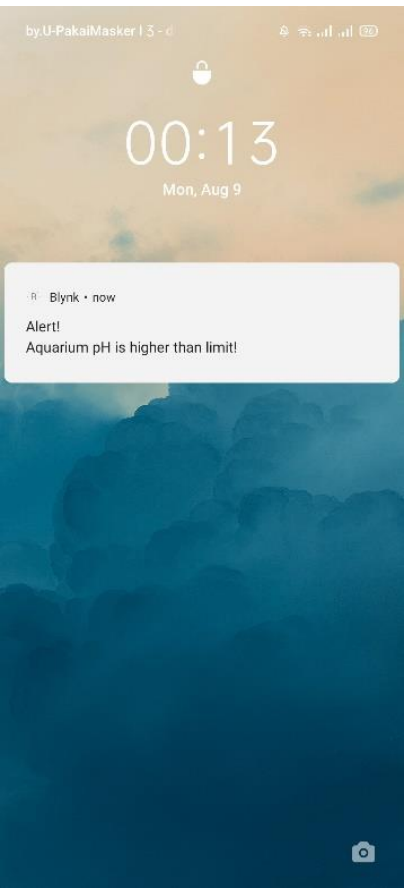

(c)

Fig. 8. Graphical user interface (a), web server displays (b), and (c) the notification of the prototype.

\section{CONCLUSION}

A real-time aquarium monitoring that can monitor fish photos, temperature and $\mathrm{pH}$ conditions on the smartphone has been successfully designed. The monitoring results on this prototype were tested in 5-minute intervals with five sampling times. The average error for temperature is $0.14 \%$ and for $\mathrm{pH}$ is $0.67 \%$. These results indicate that the measurements made by the prototype are linear with reference data. In addition, this prototype can be further developed by adding features for temperature and $\mathrm{pH}$ control.

\section{Acknowledgments}

This work has been supported by Pekan Kreativitas Mahasiswa 2021 from the Ministry of Education, Culture, Research, and Technology Republic of Indonesia. 


\section{REFERENCES}

[1] Sukardiyono and D. Rosana, "Megabiodiversity Utilization through Integrated Learning Model of Natural Sciences with Development of Innertdepend Strategies in Indonesian Border Areas" in IOP Conference Series: Journal of Physics, 2019. https://doi.org/10.1088/1742-6596/1233/1/012099

[2] Y. Timorya, A. Abdullah, A. S. Batubara and Z. A. Muchlisin, "Conservation and economic status fishes in the Krueng Sabee River, Aceh Jaya District, Aceh Province, Indonesia," in IOP Conference Series: Earth and Environmental Science, vol. 216, no. 1, p. 012044, 2018. https://doi.org/10.1088/1755-1315/216/1/012044

[3] M. Nurmufida, G. H. Wangrimen, R. Reinalta and K. Leonardi, "Rendang: The treasure of Minangkabau," Journal of Ethnic Foods, vol. 4, no. 4, pp. 232-235, 2017. https://doi.org/10.1016/j.jef.2017.10.005

[4] D. O. Mahara and M. H. S. Kurniawan, "Survival Analysis Based on Average Response Time of Maritime Search and Rescue (SAR) Incidents in 2019 Using Kaplan-Meier Method and Log-Rank Test," ENTHUSIASTIC: International Journal of Applied Statistics and Data Science, vol. 1, no. 1, pp. 7-12, 2021. https://doi.org/10.20885/enthusiastic.vol1.iss1.art2

[5] G. S. Haryani, "Sustainable use and conservation of inland water ecosystem in Indonesia: Challenge for fisheries management in lake and river ecosystem," in IOP Conference Series: Earth and Environmental Science, Vol. 789, No. 1, p. 012023, 2021. https://doi.org/10.1088/1755-1315/789/1/012023

[6] O. Oyebanji, G. Salako, L. Nneji, S. Odadipo, K. Bolarinwa, E. Chukwuma, A. Ayoola, T. Olagunju, D. Ighodalo and I. Nneji, "Impact of climate change on the spatial distribution of endemic legume species of the GuineoCongolian forest, Africa," Ecological Indicators, vol. 122, 2021. https://doi.org/10.1016/j.ecolind.2020.107282

[7] H. Yilmaz, O. Y. Yilmaz and Y. F. Akyüz, "Determining the factors affecting the distribution of Muscari latifolium, an endemic plant of Turkey, and a mapping species distribution model," Ecological Indicators, vol. 7, no. 4, 2021. https://doi.org/10.1002/ece3.2766

[8] S. Alfonso, M. Gesto and B. Sadoul, "Temperature increase and its effects on fish stress physiology in the context of global warming," Journal of Fish Biology, vol. 98, pp. 1496-1508, 2020. https://doi.org/10.1111/jfb.14599

[9] S. B. Bedassa, "Identification of possible causes of fish death in Lake "Lake Kabo"," International Journal of Fisheries and Aquaculture, vol. 11, no. 2, pp. 29-36, 2019. https://doi.org/10.5897/IJFA2018.0721

[10] K. Marimuthu, H. Palaniandy and Z. A. Muchlisin, "Effect of different water $\mathrm{pH}$ on hatching and survival rates of African catfish Clarias gariepinus (Pisces: Clariidae)," Aceh Journal of Animal Science, vol. 4, no. 2, pp. 80-88, 2019. https://doi.org/10.13170/ajas.4.2.13574

[11] V. C. Mota, J. Hop, L. A. Sampaio, L. T. N. Heinsbroek, M. C. Verdegem, E. H. Eding and J. A. J. Verreth, "The effect of low $\mathrm{pH}$ on physiology, stress status and growth performance of turbot (Psetta maxima L.) cultured in recirculating aquaculture systems," Aquaculture Research, vol. 49, no. 10, pp. 3456-3467, 2018. https://doi.org/10.1111/are.13812

[12] K. K. Patel, S. M. Patel, P. G. Scholar and C. Salazar, "Internet of Things-IOT: Definition, Characteristics, Architecture, Enabling Technologies, Application \& Future Challenges," International Journal of Engineering Science and Computing, vol. 6, no. 5, 2016.

[13] A. Khanna and S. Kaur, "Internet of Things (IoT), Applications and Challenges: A Comprehensive Review," Wireless Personal Communications, vol. 114, pp. 1687-1762, 2020. https://doi.org/10.1007/s11277-020-07446-4

[14] S. Kumar, P. Tiwari and M. Zymbler, "Internet of Things is a revolutionary approach for future technology enhancement: a review," Journal of Big Data, vol. 6, no. 111, 2019. https://doi.org/10.1186/s40537-019-0268-2

[15] S. Nižetić, P. Šolić, D. L.-d.-I. González-de-Artaza and L. Patrono, "Internet of Things (IoT): Opportunities, issues and challenges towards a smart and sustainable future," Journal of Cleaner Production, vol. 274, 2020. https://doi.org/10.1016/j.jclepro.2020.122877

[16] R. H. Hardyanto, A. Asmara and P. W. Ciptadi, "Smart Aquarium Based On Internet of Things," Journal of Business and Information Systems, vol. 1, no. 1, 2019. https://doi.org/10.36067/jbis.v1i1.12

[17] N. A. J. Salih, I. Hasan and N. I. Abdulkhaleq, "Design and implementation of a smart monitoring system for water quality of fish farms," Indonesian Journal of Electrical Engineering and Computer Science, vol. 14, no. 1, pp. 4450, 2019. https://doi.org/10.11591/ijeecs.v14.i1.pp44-50

[18] P. Periyadi, G. I. Hapsari, Z. Wakid and S. Mudopar, "IoT-based guppy fish farming monitoring," TELKOMNIKA Telecommunication, Computing, Electronics and Control, vol. 18, no. 3, pp. 1538-1545, 2020. https://doi.org/10.12928/telkomnika.v18i3.14850

[19] M. M. Khan, "An IoT Based Smart Water Monitoring System for Fish Firming in Bangladesh," in 5th International Electronic Conference on Water Sciences session New sensors, New Methods and Technologies, New Approaches, 2020. https://doi.org/10.3390/ECWS-5-08044

[20] O. A. Nasir and S. Mumtazah, "IoT-Based Monitoring of Aquaculture System," MATTER: International Journal of Science and Technology, vol. 6, no. 1, pp. 113-137, 2020. https://doi.org/10.20319/mijst.2020.61.113137

[21] P. B. B. Jr. and O. E. Llantos, "Design and Implementation of Real-Time Mobile-based Water," in th Information Systems International Conference 2017, Bali, 2017. https://doi.org/10.20319/mijst.2020.61.113137

[22] G. Fabregat, J. A. Belloch, J. M. Badía and M. Cobos, "Design and Implementation of Acoustic Source Localization on a Low-Cost IoT Edge Platform," IEEE Transactions on Circuits and Systems-II: Express Briefs, vol. 67, no. 12, pp. 3547-3551, 2020. https://doi.org/10.1109/TCSII.2020.2986296

[23] I. Koene, V. Klar and R. Viitala, "IoT connected device for vibration analysis and measurement," HardwareX, vol. 7, 2020. https://doi.org/10.1016/j.ohx.2020.e00109

[24] S. V. Gaikwad, A. D.Vibhute, K. V. Kale and S. C. Mehrotra, "An innovative IoT based system for precision farming," Computers and Electronics in Agriculture, vol. 187, 2021. https://doi.org/10.1016/j.compag.2021.106291 
[25] N. Kothari, J. Shreemali, P. Chakrabarti and S. Poddar, "Design and implementation of IoT sensor based drinking water quality measurement system," Materials Today: 2021. https://doi.org/10.1016/j.matpr.2020.12.1142

[26] H. Helmy, A. Nursyahid, T. A. Setyawan and A. Hasan, "Nutrient Film Technique (NFT) Hydroponic Monitoring System," JAICT, Journal of Applied Information and Communication Technologies, vol. 1, no. 1, 2016. https://doi.org/10.1109/COMNETSAT.2017.8263577

[27] D. Petrov, K.-F. Taron, U. Hilleringmann and T.-H. Joubert, "Low-cost Sensor System for on-the-field Water Quality Analysis," in 2021 Smart Systems Integration (SSI), 2021, $\quad$ pp. 1-4. https://doi.org/10.1109/SSI52265.2021.9466956

[28] S. Nuanmeesri, L. Poomhiran and P. Kadmateekarun, "Face mask detection and warning system for preventing respiratory infection using the internet of things," COMPUSOFT, An international journal of advanced computer technology, vol. 9, no. 9, pp. 3810-3816, 2020. https://ijact.in/index.php/ijact/article/view/1205

[29] H. Liltved and B. Landfald, "Effects of high intensity light on ultraviolet-irradiated and non-irradiated fish pathogenic bacteria," Water Research, vol. 34, no. 2, pp. 481-486, 2000. https://doi.org/10.1016/S00431354(99)00159-1

[30] M. S. Chawla, D. Prakash and S. Jindal, "Design of system for measuring air properties for help during COVID-19 scenario," Materials Today: Proceedings, vol. 45, no. 6, pp. 4472-4476, 2021. https://doi.org/10.1016/j.matpr.2020.12.987

[31] W. A. Jabbar, C. W. Wei, N. A. A. M. Azmi and N. A. Haironnazli, "An IoT Raspberry Pi-based parking management system for smart campus," Internet of Things, vol. 14, 2021. https://doi.org/10.1016/j.iot.2021.100387

\section{BIOGRAPHY OF AUTHORS}

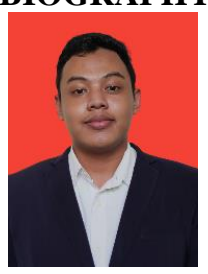

Naufal Inas Fikri is currently pursuing a bachelor's degree in electrical engineering at, Department of Electrical Engineering, Faculty of Engineering, Universitas Indonesia. Email: naufal.inas@ui.ac.id

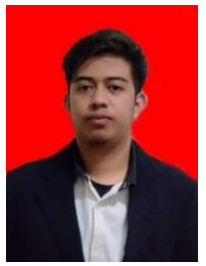

Vito Louis Nathaniel is currently pursuing a bachelor's degree in electrical engineering at, Department of Electrical Engineering, Faculty of Engineering, Universitas Indonesia. Email: vito.louis@ui.ac.id

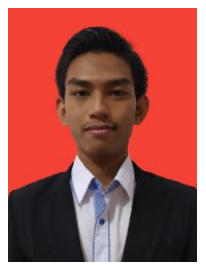

Muchamad Syahrul Gunawan is currently pursuing a bachelor's degree in electrical engineering at, Department of Electrical Engineering, Faculty of Engineering, Universitas Indonesia. Email: muchamad.syahrul@ui.ac.id

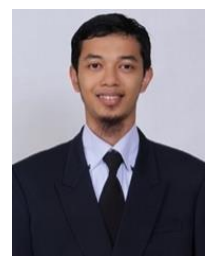

Tomy Abuzairi received the B. Eng degree in electrical engineering from the Department of Electrical Engineering, Universitas Indonesia, in 2009, the M.Sc degree (double degree program) in optoelectronic engineering and electrical engineering from National Taiwan University of Science and Technology, and Universitas Indonesia, in 2012, the Ph.D. degree (double degree program) in a graduate school of science and technology, and electrical engineering from Shizuoka University and Universitas Indonesia, in 2016. He joined the Department of Electrical Engineering, Universitas Indonesia, in 2017, where he is currently an Assistant Professor. He has authored or co-authored over 40 articles published in refereed journals and conferences. He holds several patents for instrumentation and sensor. His research interests include biomedical instrumentations, optoelectronic, plasma technology, nanotechnology, and sensor. Email: tomy.abuzairi@ui.ac.id 